\title{
THE IMPORTANCE OF COMPANY OWNERSHIP AND BUSINESS TRANSACTION DATA INTEGRATION IN SUPPORTING THE EFFORTS TO PREVENT AND ERADICATE CORRUPTION IN INDONESIA ${ }^{1}$
}

\author{
Budi Saiful Haris \\ Sekolah Tinggi Manajemen Industri - Kementerian Perindustrian Republik Indonesia \\ E-mail: budisaifulharis@gmail.com
}

\author{
ARTICLE INFORMATION \\ Article history: \\ Received July 31, 2015 \\ Revised November 30, 2015 \\ Accepted February 22, 2016

\section{JEL Classifications} \\ M20
}

\section{Key Words:}

Company ownership,

Transaction data,

Prevent and Eridicate Corruption

\section{DOI:}

10.21532/apfj.001.16.01.01.06

\begin{abstract}
Corruption is commonly committed by leaving no official trace. In disclosing big corruption cases, investigators are often challenged by defendant who always seeks to make an alibi on the charges of the investigators such as by creating fake or underlying business. The application of the principle of shifting burden of proof by the defendant could actually be detrimental to the prosecution process if the public prosecutor fail to prove to the contrary on the argument or evidence submitted by the defendant who is trying to deny the charge of public prosecutor. Such condition may occur due to the possibility that the defendant could convey some evidence of business transactions and sources of information that might not be successfully acquired by the public prosecutor, law enforcers and other relevant government agencies prior to the prosecution process. In this case, there is a big possibility that the perpetrators have manipulated financial transaction information assisted by the gatekeepers. The following entries parse the root of the problem for the matter and provide recommendations for the integration of business transparency approach to prevent and eradicate corruption by making breakthroughs that could prevent from the usage of fake financial transaction information as the evidence that could obscure the crime of corruption.
\end{abstract}

\section{INTRODUCTION}

A research conducted by Stolen Asset Recovery (StAR) Initiative, the World Bank, and United Nation Office on Drugs and Crime (UNODC) has resulted a conclusion that as many as 128 of 150 mega corruption cases in various countries involve companies that conceal the ownership and control the proceeds of crime. In Indonesia, there has

The 2nd Runner Up of 2015 Call for Papers of 
been no comprehensive study on the utilization of companies for such purposes. However, it can be witnessed together today that some of the corruption cases have involved companies which are made as both the main means of committing corruption and facilities of crime. The perpetrators utilize the company with the purpose of deceiving crime detection, as a means of committing a crime and / or obscuring the origin of the proceeds of crime in order to look as if they were the results of a legitimate business (money laundering).

The corruption case dragging the former Chairman of Constitutional Court, Akil Mochtar, for example, involved a company named CV Ratu Samangat, established in 2010. It was recorded that the owner and management of the company were Akil Muchtar's wife and children. The company establishment was necessarily suspected as an attempt to deceive the detection of suspicious financial transactions by financial industry. By using the name of the company, they made an account to receive payments from third parties with the inclusion of the fake / underlying businesses such as sales and purchase of oil palm and heavy equipment. Most transactions were successfully proven by the investigators as fictitious transactions. The transactions, in fact, were used for the settlement of election dispute cases handled by Akil Mochtar.

In the case of Videotron involving Riefan Avrian, the son of Syarifuddin Hasan, the former Minister of Cooperatives and SMEs, there is a modus using a company called PT Imaji Media. The company was established in 2012 in which Riefan Avrian appointed his office boy and clerks as the board of directors and commissioner of the company. The company was utilized by Riefan Avrian to win Videotron project bidding in the Ministry of Cooperatives and SMEs Office in 2012 with the value of IRD 23.5 billion. During the trial, Riefan Avrian admitted on the establishment of PT Imaji Media and the appointment of his office boy and employees as the board of directors and board of commissioners of the company to obscure his name, or to keep away from the beneficial owner identification.

One of the mega corruption cases involving the modus of establishment or engagement of company is the case of Nazaruddin, the former treasurer of Democratic Party and a Member of Parliament of Indonesia. In the development of this case, there appeared the establishment of 38 companies under Permai Group by Nazaruddin to work on projects funded by the state budget (APBN) in various government agencies. The projects in Government Agencies were easily acquired by Nazaruddin's companies by utilizing the influence of his closeness to the members of Parliament and the people in the Ministries. A number of Nazaruddin's companies were made in separate management, and Nazaruddin deliberately did not put his name in the record of the company ownership but appointed or placed his employees as board of directors and board of commissioners of the companies.

From the cases mentioned above, it can be seen that there is a modus of company establishment on the phase of ante factum, or 
before committing corruption. The success in disclosing these cases cannot be separated from the strategy, cooperation and commitment of various parties, including law enforcers, government agencies and the public. In other cases, the modus of company establishment and business transactions can occur on the phase of post factum, or after committing corruption. In the case of Bahasyim Asyifie, for example, the law enforcers identified the existence of unusual wealth owned by the former Staff / Officer of the Directorate General of Taxes and his family. The origin of the wealth cannot be traced by the law enforcers whether it is acquired from corruption or legitimate business, given that the financial transactions conducted by Bahasyim Asyifie and his family had been made in cash since 1998. The velocity of money in Bahasyim's and his family's accounts also did not reflect any given business transaction. The funds were only played on banking and insurance investment sectors such as deposits. The law enforcers, in this case, identified the company owned by the Bahasyim's that was just established in 2005, and it did not indicate any significant value of business transactions.

Based on the cassation decision in the Supreme Court at the end of 2011, Bahasyim Assifie was found guilty and sentenced to 12 years in prison and the Court also seized all of the defendant's wealth as much as IDR 60.9 billion and US \$ 681,147 for the state. In mid 2012, Bahasyim proposed a judicial review by stating that his wealth was acquired from several businesses he had ever run such as plumbing installation, contractor, sale and purchase of foreign currency, sale and purchase of cars, sale and purchase of stationery, partnership in bidding, sale and purchase of building materials, sale and purchase of gems, photographic services, sale and purchase of land and houses.

In addition to the cases that have been successfully disclosed and brought to trial, there are still many cases of corruption and money laundering which have not been accomplished yet. Besides, some cases have to be terminated by investigators due to insufficiency of evidence to prove the guilt of the suspect and also the presence of new facts (post pactum) on the origins of the assets proposed after the process of investigation / inquiry which are not successfully identified or excavated before based on the accessible sources of information (ante pactum), and this finally breaks the initial information from an alleged corruption or money laundering. The new facts on the origins of the wealth, among others, are from sale and purchase of (land, houses, motor vehicles, and foreign currency), loan, heritage, business venture, savings / investment, gift from parents, source of funds from other parties (entrustment), and others.

The emergence of various issues above indicates the importance of the study of regulation and sources of information related to company ownership and business transactions in Indonesia. The study, among others, is aimed to identify any weaknesses in the system of law that could potentially be exploited by the perpetrators of corruption and money laundering. This study is expected to provide 
recommendations for the improvement of the prevention and eradication of corruption.

\section{THEORITICAL FRAMEWORK} TYPE AND REGULATION OF BUSINESS ESTABLISHMENT AND BUSINESS LICENSING

\section{Types and Characteristics of Business}

Types of business commonly used are individual company (merchant), partnerships, corporations, and trusts. The major differences of the business types are on the capital structure, business management, sharing of benefits and risks of the business.

Individual company is a type of non legal business entity. This company is usually owned and managed only by an individual who also bears all risk by himself. On the one hand, this type of company has an advantage in terms of not requiring complicated establishment and formal deed. The owner has freedom in managing the corporate finance. The company of this type, however, is difficult to develop because of the difficulty in managing the business which is just handled by one hand.

Limited partnership / Vennootschap Commanditaire / CV usually originates from individual businesses or family businesses that want to grow and have legality to be able to conduct their business safely under the law. The company is also categorized as a non-legal business entity. In_Limited Partnership, there are two kinds of partner, namely (1) active partner who is responsible for the management, utilization, and activities of the company business, and (2) passive partner who is just releasing the money (capital) and waiting for the profits. In running the company's business activities, active partner will bear the loss up to his personal wealth. While passive partner, whose function is only as a capital provider, his responsibility is only on the capital he has provided to $\mathrm{CV}$ and does not include personal possessions.

$\mathrm{CV}$ is set in Article 16 to 35 of Commercial Code of Law. The process of CV establishment is done by making a Notary Deed (Authentic), and registering to the District Court at the domicile / jurisdictions of the $\mathrm{CV}$, by providing terms of completeness required such as Company Domicile Certificate and Taxpayer Identification Number (TIN) on behalf of the CV concerned.

When the CV participates in an auction / bidding conducted by government agencies or other institutions, it must be equipped with other legal documents, such as Letter of Taxable Entrepreneur, Business License, Certificate of Company Registration, and others as required.

Limited Liability Company (PT) is a legal business entity that is considered providing more legal certainty in business. In the Limited Liability Company there is a separation between shareholder's personal wealth and company's wealth. In Limited Liability Company, the business activities are operated by the company's organs consisting of General Meeting of Shareholders, the Board of Commissioners and Board of Directors. Each organ has its own capacity and obligation in running the company's business activities. With the existence of separate company organs, the 
company is considered having better function of monitoring.

The business type and activities as well as the procedures for the implementation of the Limited Company's activities are regulated in the articles of association made in Notary Deed and must be registered and approved by Ministry of Law and Human Right. In terms of capital and shareholdings, Limited Company (PT) is deemed easier to develop by way of raising funds from investors through the sale of shares or acquisition.

In addition to the business types mentioned above, there is also a business type called trust. The basic concept of trust includes a person who holds property for the benefit of one person to another. The concept of trust is not recognized in the Indonesian legal system. However, the investigators should understand the basic laws of trust because companies and criminals in Indonesia are using trust outside the jurisdiction of Indonesia (offshore).

\section{Aspects of Business Taxation}

In terms of taxes, individual company is still required to pay taxes. Or in this case, the owner does not necessarily pay corporate tax, but individual tax remains levied to all income. In 2013, the Ministry of Finance issued Regulation No. 197 / PMK.03 / 2013 on the Limitation of Small Firm Value Added Tax that provides limitation on the definition of Small-scale Businesses that are required as the Taxable Entrepreneur. In this case, the businessman who, in a financial year, delivers taxable goods and / or services that have a gross circulation and / or gross receipt of more than
4.8 billion is confirmed as taxable entrepreneur. Previously, the regulations only stipulated a limit of IDR 600 million in the financial year. As a taxable entrepreneur, the businessman is required to withhold, deposit and report value added tax and sales tax of the payable luxury goods on the handover of taxable goods and / or taxable services he accomplished.

There is a little difference in taxation for $\mathrm{CV}$, in which the tax treatment on the salaries and / or distribution of profits received by the owners of capital is not an object of Article 21 of Income Tax, and the income divided is not an object that is free from tax reduction. So in this case, $\mathrm{CV}$ does not perform any calculation and tax reduction for the salary received and the business profits distributed to the members of the CV.

Meanwhile, from the aspect of taxation, the shareholders and the Limited Company are two different and separate Taxpayers. So, if there is a transfer of assets or wealth in the form of resources from the company to the owner, it means that there is a transfer flow of income. Thus, the dividend received by shareholders is considered as taxable income. On the contrary, since the dividend is calculated from the profit after tax, the dividend, at the side of the company, will not affect the amount of business profits or operating profits to be taxed. It could be said that the tax for the profit or operating income is imposed to the PT, and when the profit is distributed to the shareholders, the tax will be imposed again to the shareholders (individual). 


\section{Document of Legal Licenses}

In addition to the characteristics, there are other legal documents relating to the existence of general business license, namely:

a. Business Domicile Certificate

Business Domicile Certificate states the domicile of a person or a business entity. The Domicile Certificate is required to prepare other various legal documents such as Business License, Certificate of Company Registration, Taxpayer Identification Number (TIN), and other trading businesses. The Domicile Certificate is made at the Village Office or Sub-District Office. There are no sanctions for the absence of this domicile certificate, but the preparation for other licensing will be hampered without this certificate. This certificate is absolutely necessary in preparing various licenses, especially to open a new business.

b. Taxpayer Identification Number (TIN) Taxpayer Identification Number (TIN) is the number given to the taxpayer as a means of tax administration that is used as personal identification or identity of the taxpayer in carrying out their rights and obligations in taxation. TIN serves as:

1) As a means of tax administration.

2) As a personal identification or taxpayer identity in carrying out his rights and obligation in taxation.

3) Generally posted in any tax documents.

4) Maintaining order in the payment of taxes and tax administration supervision.
Any person deliberately fails to enroll or misuse or use without the right of taxable entrepreneur confirmation that could be detrimental to the state revenues shall be punished with 6 (six) years of imprisonment and a fine maximum four (4) times as much as the tax payable that is not paid or less payment. Based on Regulation No. 31 of 2009 on technical guidelines and procedures for the reduction of the payment of Income Tax Article 21, Article 20;

1) For the income recipient, based on Income Tax Article 21, who does not have TIN should be imposed reduction of income tax article 21 with the rate of $20 \%$ (twenty percent) higher than that applied to the taxpayer who has TIN.

2) The amount of Income Tax Article 21 that should be reduced as referred to in paragraph (1) is $120 \%$ (one hundred and twenty percent) of the Income Tax Article 21 which should be reduced in case the individual concerned already has TIN.

3) The reduction of Income Tax Article 21 as referred to in paragraph (1) only applies to the reduction of Income Tax Article 21 that is not final.

4) In case of permanent employee or recipient of periodic pension as the recipient of income that has been reduced by Income Tax Article 21 with a higher rate as referred to in paragraph (1), should register to obtain TIN in the calendar year concerned, at the latest before the reduction of Income 
Tax Article 21, for the tax period in December. The Income Tax article 21 which has been reduced from the difference in the imposition of the rate of $20 \%$, or which is higher, is calculated by Income Tax Article 21 outstanding for the following months after having the TIN.

\section{c. Commerce License}

Commerce License is a license to carry out trading business activities. Every company, cooperative, partnership or individual company that undertakes trading business must obtain a License issued based on the company domicile and applicable throughout the territory of the Republic of Indonesia.

The commerce License must be owned by individuals or entities that have trading business, and it serves as a tool or evidence of endorsement of the trading business. Commerce License is issued by the local government and is needed by individual business and the businesses that have legal entity. Commerce License is not only needed by large scale enterprises but also small and medium enterprises in order that the business undertaken can get the recognition and approval from the government.

There are several types of commerce License (Small, Medium, Large and Micro) that are provided based on the size of capital and net worth, with the explanation as follows:

a. Small Commerce License: must be owned by the trading company with capital and net worth totaling IDR 50 million to 500 million, excluding land and buildings.

b. Commerce License: must be owned by the trading company with capital and net worth totaling IDR 500 million to 10 billion, excluding land and buildings.

c. Big Commerce License: must be owned by the trading company with capital and net worth totaling more than IDR 10 billion, excluding land and buildings.

d. Micro Commerce License: is a license that can be granted to micro trading company with capital and net worth of not more than IDR 50 million.

The Commerce License is issued based on the domicile of the owner or person in charge of the company. Commerce License for small and medium enterprise is issued and signed by the Head of Trade and Industry Regency Office on behalf of the Minister. While the Commerce License for large enterprises is issued and signed by the Head of Trade and Industry Province Office on behalf of the Minister.

Any companies performing trading business are obliged to have Commerce License. Pursuant to Article 4 paragraph (1) letter c Trade Minister Regulation No. 46/2009, there is an exception to the obligation to own Commerce License for Micro Trading Company with the following criteria: 
a. Individual or partnership venture;

b. The business activities are managed and operated by the owner or close family members; and

c. Having a maximum net worth of IDR 50,000,000 excluding land and buildings.

However, micro trading company can still acquire Commerce License if it is required by the company.

The Commerce License is valid as long as he trading company is carrying out its business activities. The trading company referred shall re-register every five (5) years in the place where the License is issued.

In practice, the ownership of Commerce License is beneficial for the following activities:

a. As a validation tool that is given by the government so that there is no licensing problem in business activities.

b. As a prerequisite in licensing the export and import.

c. As a prerequisite in taking part in bidding held by the government.

\section{d. Certificate of Company Registration}

Each company, either in the form of legal entity, cooperative, individual, or others must have Certificate of Company Registration. Company Registration Certificate is considered valid as long as the company is still in operation and must be re-registered every 5 (five) years. The legal basis for the obligations is stipulated in the Law of the Republic of Indonesia No. 3 of 1982 on Company Registration Requirement, and the Decree of the Minister of Industry No.: 596 / MPP / Kep / 9/2004 on Company Registration Requirement Standard. Article 5 of Law No. 3 of 1982 stated that every company shall be registered in the Company Registration.

Company Registration Certificate is a proof that the company or business entity has been doing its obligation to register the company in the Company Registration. In principle, the Company Registration aims to note information of a company, and as a source of official information for the parties concerned. The information can include the identity and other information about the company

The registration of the company is done on the company registration office at the company office domicile or at the domicile of any branch office, auxiliary office or subsidiary office. Registration must be made within a period of three months after the company begins to operate.

\section{BUSINESS TRANSACTION}

\section{CHARACTERISTIC AND SUPERVISION}

Transaction has a very large understanding and classification. Article 1 (3) of Law No. 8 of 2010 on the Prevention and Eradication of Money Laundering provides a definition of transaction as all activities creating rights and / 
or obligations, or give rise to a legal relationship between two or more parties.

The definition implicitly contains meanings or restrictions on the validity of a transaction. A valid or legal transaction would be binding on the parties, both from private and public dimensions. In private dimension, the transaction will bind rights and obligations relating to the physical transition and ownership of the goods and the rights and obligations relating to the payment by the buyer to the seller. While in public dimension, a particular transaction is regulated by legislation. In addition, there is also an obligation to register the ownership transfer registration and the taxation which is intended to order the administration, to avoid potential disputes and to contribute to the distribution of welfare of the people.

The supervision of transactions in connection with the aspect of taxation begins with a self-assessment by the taxpayer through Tax Returns. Then, to test the compliance of the fulfillment of tax obligations can be examined by the Directorate General of Taxation.

The regulations and supervisions for specific transaction are more stringent than other for transactions. For example, in connection with the transaction by the Government, the audit is performed regularly by the Financial Investigation Bureau as a form of control over the management and accountability of the state finances.

Article 68 of Law No. 40 of 2007 on Limited Liability Company also mandates an audit of the financial statements derived from: a. Business Activities of the Company that raise and / or manage the public's money;

b. The Company that is issuing a letter of debt acknowledgement to the state;

c. The Company is a go public company;

d. The Company has assets and / or the amount of business circulation of at least IDR 50 Billion;

e. Required by legislation.

The Decree of Minister of Industry and Trade No. 121 / MPP / Kep / 2/2002 on the Procedure of Presentation of Annual Financial Statements provides that any company having head office status, domiciled and conducting business activities in the territory of the Republic of Indonesia is obliged to submit the company's annual financial statement to the Directorate of Business Development and Corporate Registration.

Certain types of transactions through financial service providers or goods and services providers also get special attention with the existence of reporting mechanism to the Indonesian Financial Transaction Reports and Analysis Center (PPATK) by the reporting party in accordance with the provisions of Law No. 8 of 2010 on the Prevention and Eradication of Money Laundering. The reporting party in this case is subject to the obligation to conduct Customer Due Diligence (CDD), to determine the risk ranking to its customers, to monitor the transactions and to present the report to Indonesian Financial Transaction Reports and Analysis Center (PPATK). CDD is also aimed 
to identify the beneficiary owner (handler / owner / principal beneficiary) of a company. By identifying the beneficiary owner thoroughly, it is expected to be able to monitor the misuse of company's accounts in connection with a crime, including corruption.

Any supervision performed has its own advantage, weakness and challenge. The supervision of transactions in connection with taxation, for example, has experienced a major challenge that until today the number of obedient taxpayers is only less than $50 \%$ of the real potential. On the other hand, there are many cases of taxation related to the issuance of fictitious tax invoices or not based on the actual transactions that cause the reduction in potential state revenue or even dredge the state money through fictitious_restitution. The number of cases of issuance of fictitious tax invoices and fictitious restitution, one of which is caused by the weakness of the state in monitoring business transactions. In this case, not all transactions are successfully confirmed.

In auditing the state finance, the Financial Investigation Bureau (BPK) has identified many big cases of corruption based on the trigger of the investigation of state financial management. However, it still faces challenges in which the assessment of fairness of the state finance with an unqualified opinion (WTP) does not guarantee zero corruption in the institution that is given such assessment. Perpetrators of corruption in this case just understand the standards that must be met so that his institution can achieve unqualified opinion (WTP), and try to keep away from the detection of financial investigation by making complex schemes beyond the reach of the audit of the Financial Investigation Bureau (BPK).

The existence of an audit by the Public Accounting Firm has significant potential in the disclosure of mega cases of corruption involving private sector. The corruption committed by private sector, for example, can occur when the management of the company gets involved in bribing government officials in order to obtain greater profits, indications of fictitious restitution causing the loss of state funds, misuse of state funds in the foundation and others. However, these have not become a serious concern given that the activities of Public Accounting Firm are currently still very dependent on the user or stakeholder. The entire findings of Public Accounting Firm will be forwarded to the user or stakeholder who hires the Accounting Firm in which the secrecy is secured by the code of professional conduct. The optimal participation of Public Accounting Firm in the prevention and eradication of corruption is expected to be realized by making the Public Accounting Firm as the reporting party to the approach to anti-money laundering based on the Government Regulation No. 43 of 2015 on the Reporting Parties in the Prevention and Eradication of Money Laundering. As a Reporting Party, Pubic Accounting Firm in this case is given the obligation to report suspicious financial transactions to Indonesian Financial Transaction Reports and Analysis Center (PPATK). This reporting is excluded from all the secrecy, including the code of professional conduct and protected by Law. 
The implementation of CDD by the Financial Service Providers, in practice, is still experiencing problems in identifying the truth of customer profile and the beneficiary owner of a company. There is a tendency for the officials, civil servants and other State administrators to obscure the real profession in order to avoid the monitoring and reporting of transactions by the Financial Service Providers. This condition can also occur due to the lack of adequate, complete and up to date access to the data of civil servants, officials and State Administrators. In regard to the monitoring of the company's clients, there is also the tendency in which the crime perpetrator, including corruptor as the beneficial owner, avoids the inclusion of his name as the official owner / caretaker in the documents and company license. For this purpose, the perpetrator often makes changes to the company's management data in the official documents.

\section{CONCLUSIONS AND RECOMMENDATIONS:}

\section{INTEGRATING BUSINESS}

\section{TRANSPARENCY APPROACH} TO PREVENT AND ERADICATE

\section{CORRUPTION}

In many cases, transactions of corruption, either in the form of bribery, extortion, commission, gratuity or others, are committed without leaving official trace. By the time the investigators manage to identify a criminal act of corruption, and want to dismantle the larger crime, the investigators are sometimes faced with the challenge in which the perpetrator tries to make an alibi of justification on the suspicion of investigators, among others, by making the fake or underlying business.

In the proceedings, the implementation of the principle of shifting burden of proof by the defendant in Indonesia has not been able to be applied purely. Even when this is applied, it is in fact detrimental to the prosecution if the public prosecutors fail to prove to the contrary on the argument or evidence submitted by the defendant who seeks to deny the charges. This condition may occur, one of which, because there is possibility that the perpetrator conveys the evidence of business transactions from the sources of information that are not successfully acquired by the public prosecutors or other law enforcers or government agencies concerned prior to the prosecution process. In this case, there is a possibility that the perpetrator has manipulated the financial transaction information assisted by the gatekeepers.

Judging these problems, the prevention and eradication by law should integrate business transparency approach by making breakthroughs that could prevent the utilization of manipulated financial transaction information as the evidence that could obscure the crime of corruption. One of the breakthroughs is by encouraging the transparency of company ownership and licensing and business transactions that can be supported by official documents and through the means that can be verified to become the proof of validity or validation of business ownership or business transactions. 
The concept is applied in some countries, in which the ownership of a certain company or business must be supported by the registration of identity / company profile / business on the government official database that is constantly updated. As for the truth of the business transactions can be verified, the most valid channel is by using transfer in the financial system. It becomes the main item in setting the restrictions of cash transactions in some countries such as Italy, Argentina, Russia, Mexico, Greece, France, Belgium and Armenia. In this case, the transaction of business in nominal and certain conditions must be conducted by transfer. The opposite condition is causing the invalidity of a transaction.

This, at least, can prevent the use of underlying ownership of companies and shell company as the mask that obscures the wealth of crime, including corruption. Shell company usually has no economic activity and other documents that can be verified. While normal company, besides the existence of economic activity, it is also involved in several activities such as marketing, becoming a member of an association, having a website, purchasing supplies and equipment. In addition, normal company can be traced from the existence of employees who can be interviewed, documents related to various company decision-makings, and ability to generate financial data that can be compared to industry benchmarks.

The existence of complete database support that can be updated, accessed and processed easily and the existence of the verification support on the correctness of the transaction will be very helpful in handling more complex cases. Such supports will also be highly dependent on the cooperation of various law enforcers and relevant agencies including private sector and the public.

From the foregoing description of the type and regulation of the company establishment and business licensing, there has been regulation governing the obligation of various licenses, taxation aspects and others in connection with the business, either conducted by individuals or companies, but in reality, there is still no integrated database system for the data management and data update. The data of company management / businesses registration are still separated in each Ministry / local office where there has not been data pooling management to process and analyze the company's overall data compilation. The availability of data on the relevant agencies is still in the form of printed directories.

In regard to the prevention and eradication of corruption involving civil servants, officials, law enforcers or other state administrators, various efforts mentioned above must be supported by determining higher standards considering their position that is viewed as the educated and skilled group. In this case, the efforts need to be supported or strengthened by more obvious code of conduct on their involvement in a business in connection with conflicts of interest, regular income and assets reporting, and taxation aspects. The existence of a business or company ownership by civil servants, officials, law enforcers or other state officials or family and affiliated parties allows 
the presence of tax return reporting and the payment of income tax and value added tax of the relevant or related parties that should be done regularly and continuously. The existence of this concept would also be able to assist the public prosecutors in carrying out the liability burden of proof.

Various supports and improvements made in the future are expected to be able to initiate or support the implementation of the provisions on unexplained wealth or illicit enrichment in connection with the concept of non conviction base on asset forfeiture in Indonesia. Some of these improvements are expected to be able to complicate the efforts of corruptors to hide and utilize his proceeds of crime.

\section{REFERENCES}

Andri Gunawan, Membatasi Transaksi Tunai Peluang dan Tantangan, Tahir Foundation, Jakarta: 2013;

Emile van Der Does de Willebois, The Puppet Masters How The Corrupt Use Legal Structures to Hide Stollen Assets and What To Do About It. Star Initiative, The World Bank, UNODC, Washington: 2011;

Gunadi, Panduan Komprehensif Ketentuan Umum Perpajakan, MUC Consulting Group. Jakarta: 2010

Menteri keuangan, Peraturan No. 197/ PMK.03/2013 Tentang Batasan

Pengusaha Kecil Pajak Pertambahan

Nilai

Undang-undang Dasar Tahun 1945
Undang-undang No. 8 Tahun 2010 tentang Pencegahan dan Pemberantasan Tindak Pidana Pencucian Uang

Undang-undang No. 40 Tahun 2007 tentang Perseroan Terbatas

Kitab Undang-undang Hukum Acara Pidana

Kitab Undang-Undang Hukum Dagang

Keputusan Menteri Perindustrian dan Perdagangan No. 121/MPP/Kep/2/2002 tentang Ketentuan Penyampaian Laporan Keuangan Tahunan Perusahaan

Peraturan Pemerintah No. 43 Tahun 2015 tentang Pihak Pelapor dalam Pencegahan dan Pemberantasan Tindak Pidana Pencucian Uang

Pusat Pelaporan dan Analisis Transaksi Keuangan, Anotasi Putusan Perkara Tindak Pidana Pencucian Uang, PPATK. Jakarta: 2013 
Budi Saiful Haris : The Importance Of Company Ownership And.....

Page 71-84 